\title{
Histone H2B Type 1-A
}

National Cancer Institute

\section{Source}

National Cancer Institute. Histone H2B Type 1-A. NCI Thesaurus. Code C162920.

Histone H2B type 1-A (127 aa, $14 \mathrm{kDa}$ ) is encoded by the human H2BC1 gene. This protein is involved in the modulation of nucleosome stability in germ cells. 